\title{
Femoral artery in a Crab-eating fox: case report
}

\author{
Senos, R. ${ }^{1,2}$ and Benedicto, HG. ${ }^{1}$ \\ ${ }^{1}$ Departamento de Morfologia, Universidade Federal Fluminense - UFF, CEP 24020-206, Niterói, RJ, Brazil \\ ${ }^{2}$ Setor de Anatomia dos Animais Domésticos e Silvestres, Universidade de São Paulo - USP, \\ CEP 05508-900, São Paulo, Brazil \\ *E-mail: rafaelsenos@yahoo.com.br
}

\begin{abstract}
Despite it is widely distributed in South America, there are few data about the anatomy of the Crab-eating fox. Once the domestic dog can be used as model for clinical and surgical approaches, the anatomical differences found between the Crab-eating fox and the domestic dog are important. The aim of this study is to describe the supplied areas of the femoral artery and its respective branches in Crab-eating Fox (Cerdocyon thous) and compare them with domestic dogs. Two pelvic limbs from one adult male animal originated from the Niteroi Zoo were used. The vascular system was filled with neoprene latex and fixed with $10 \%$ formalin to make the dissection easier. The results displayed similar arrangement for the branches of the femoral artery of the Crabeating Fox in comparison with domestic dogs, except for the Lateral circumflex femoral artery. This artery not only supplied the Satorius muscle, Quadriceps femoris muscle but also the ventral part of the lateral abdominal wall. This study brings data to applied anatomy and biodiversity.
\end{abstract}

Keywords: anatomy, canidae, Cerdocyon thous, dog, vascular system.

\section{Introduction}

The Crab-eating fox is the unique species of the Cerdocyon genera which belongs the Canidae family. It is widely found in forests and fiels of South America including Colombia, Venezuela, Guiana, Suriname, east of Peru, Bolivia, Paraguay, Uruguay, north of Argentina and spread in Brazil (NOWAK, 1991; TCHAICKA, EIZIRIK, DE OLIVEIRA et al, 2007). This species has preference to nocturnal habits. It usually moves alone or in pair looking forward food (ROCHA, REIS and SEKIAMA, 2004).

Although this species have been getting attention in Parasitology recently (CATENACCI, GRISE, DA SILVA et al., 2010; LUX HOPPE, ARAÚJO DE LIMA, TEBALDI et al, 2010; NAVA, VENZAL, LABRUNA, et al 2010; SOUZA, ALMEIDA ADO, FREITAS et al 2010), we could find information in other fields of study such as anatomy (BARISSON, LOURO, DIAS et al., 2012). Classic titles, describe the anatomy of arterial system of the domestic animals in details (EVANS and CHRISTENSEN, 1979; GETTY, 1986; KÖNIG and LIEBICH, 2011) but not in wild carnivores.

Our study aimed to describe the anatomy of the femoral artery and its branches using anatomical dissection methods. We believe that the domestic dog can serve as model for medical procedures in Cerdocyon thous. This way, we also compared both species and point out the most relevant differences.

These data can be useful for zoological aspects and biodiversity data. In addition, as far as the present development of the medicine of wild mammals, the anatomical knowledge is extremely important.

\section{Case Report}

We used two pelvic limbs of an adult male of Cerdocyon thous. The specimen has been kept in captivity at Niteroi
Zoo until death with hemorrhagic enteritis symptoms. Red neoprene latex was injected through the Abdominal aorta artery to make the dissection of the Femoral artery and its branches easier. Then, the limbs were fixed with $10 \%$ formalin solution by muscular injections. The dissection of the cutaneous and subcutaneous tissue of the thigh was made showing the pelvic limb muscles, the Femoral artery and its branches. The Nomina Anatomia Veterinaria (WORLD..., 2005 ) was applied.

\subsection{Femoval Artery}

The Femoral artery of the Crab-eating fox arose in continuation of the External iliac artery when it passed through the Inguinal ligament. It ran the medial face of the thigh starting between the Pectineus and Caudal part of sartorius muscles settled cranially and the Adductor muscle settled caudally. The proximal third was covered for the Femoral fasciae and the distal third for the Gracilis and Vastus medialis head of quadriceps femoris. The first branch of the Femoral artery was laterally sent on the proximal third called Lateral Circumflex Femoral Artery. The next branch was caudally emitted around the insertion of the Pectineus muscle named Proximal caudal femoral artery. On the descending way of the artery, after the insertion of the Pectineus muscle, the Femoral artery gradually went from medial to lateral region of the tight. Then, the Femoral artery sent two muscular smaller branches. The cranial branch supplied the Vastus medialis head of the quadriceps femoris muscle while caudal branch supplied the Quadriceps femoris and the Adductor muscle. In sequence, the distal third of the Femoral artery was divided into the Saphenous artery caudal and medially, the Descending genicular artery cranially and the Middle caudal femoral artery caudally. Around the popliteal region, the Femoral artery emitted 
its last branch called Distal caudal femoral artery. The distal continuation of the Femoral artery ran between both Medial and Lateral portions of gastrocnemius muscles called the Popliteal artery. (Figure 1)

\subsection{Lateral Circumflex Femoral Artery}

The Lateral circumflex artery was the first branch of the Femoral Artery. It was a three branches trunk in the proximal third on the medial surface of the thigh. The first branch of the trunk went straightly cranially to the Cranial and Caudal parts of sartorius muscle. The second and the third were descending branches but the later one was caudal in reference to the other. They both supplied the Quadriceps femoris muscle.

\subsection{Proximal Caudal Femoral Artery}

The Proximal caudal femoral artery appeared caudally as the second branch of the Femoral artery. It ran medially to the Pectineus muscle and Adductor muscle before penetrate and irradiate into the Gracilis muscle.

\subsection{Saphenous Artery}

After the emission of two muscular branches to the Vastus medialis of quadriceps femoris muscle and the Adductor muscle, the Femoral artery generated, caudal-medially, the Saphenous artery around the middle third of the thigh. It ran superficially and medially the pelvic limb in distal direction since its origin. It was the longest branch of the Femora artery.

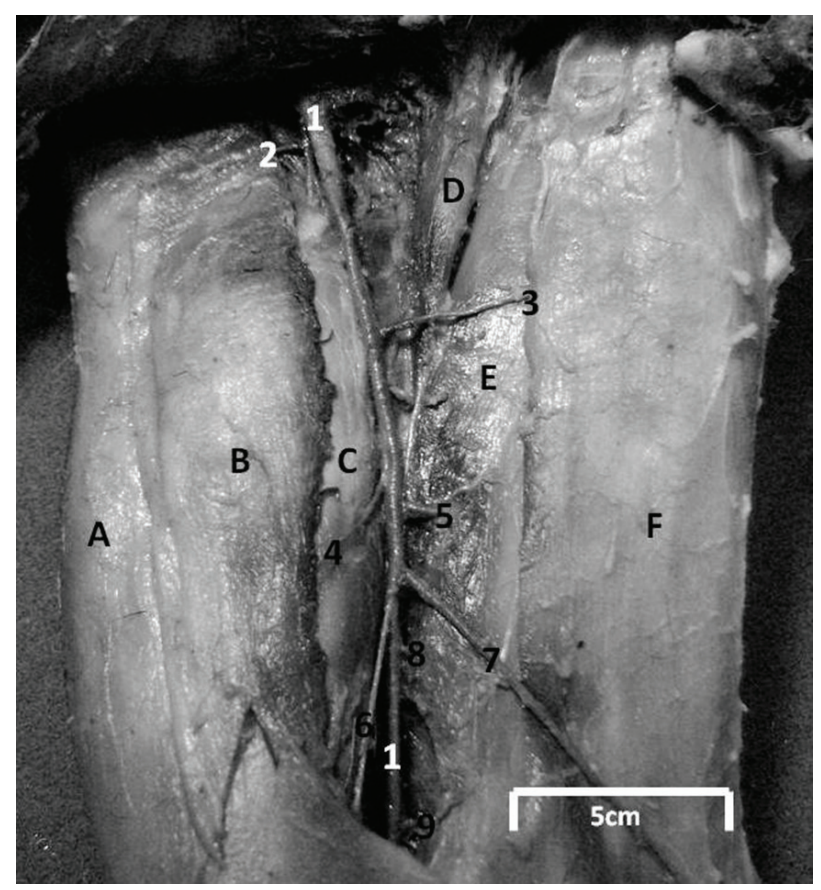

Figure 1. Arteries of right thigh, medial view. A) Cranial sartorius muscle; B) Caudal sartorius muscle; C) Quadriceps femoris; D) Pectineus muscle; E) Adductor muscle; F) Gracilis muscle; 1) Femoral artery; 2) Lateral circumflex femoral artery; 3) Proximal caudal femoral artery; 4-5) Muscular branches; 6) Genicular descending artery; 7) Saphenous artery; 8) Middle caudal femoral artery; 9) Distal caudal femoral artery.

\subsection{Genicular Descending Artery}

The Genicular descending artery was emitted cranially by the Femoral artery around the insertion of the Pectineus muscle. It supplied the distal third of the Quadriceps femoris before it reached the stifle joint.

\subsection{Middle Caudal Femoral Artery}

Just after the origin of the Saphenous and Genicular descending arteries, the Femoral artery sent the Middle caudal femoral artery straightly to the Semimebranosus muscle. This artery passed laterally to the Addcutor muscle that received a smaller branch from this artery. (Figure 2)

\subsection{Distal Caudal Femoral Artery}

The last branch of the Femoral artery appeared caudally at Popliteal region of the stifle joint. It was named Distal caudal femoral artery and runs between the Adductor and Semimembranosus muscle sending ascending, middle and descending smaller branches. (Figure 2)

\subsection{Variation}

One anatomical variation was found in the left limb considering the right one. The Lateral circumflex femoral artery was emitted as a trunk within four branches, not three. The additional branch is ascending cranially running to the abdominal wall muscles except the rectus abdominal muscle. (Figure 3)

\section{Discussion}

For surgical approaches in the medial thigh of the Crabeating fox and measurement of blood pulse, the dog is a good model in concern to vascular aspects (EVANS and

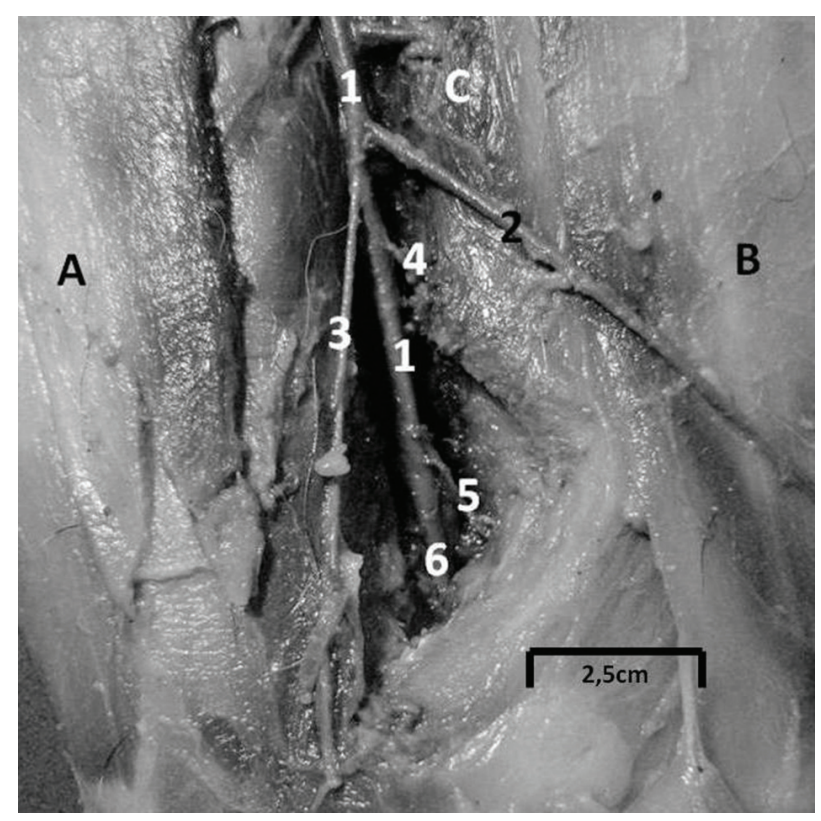

Figure 2. Branches of the Femoral artery in distal third of the right thigh, medial view. A) Cranial sartorius muscle; B) Gracilis muscle; 1) Femoral artery; 2) Saphenous artery; 3) Descending genicular artery; 4) Middle caudal femoral artery; 5) Distal caudal femoral artery; 6) Popliteal artery. 

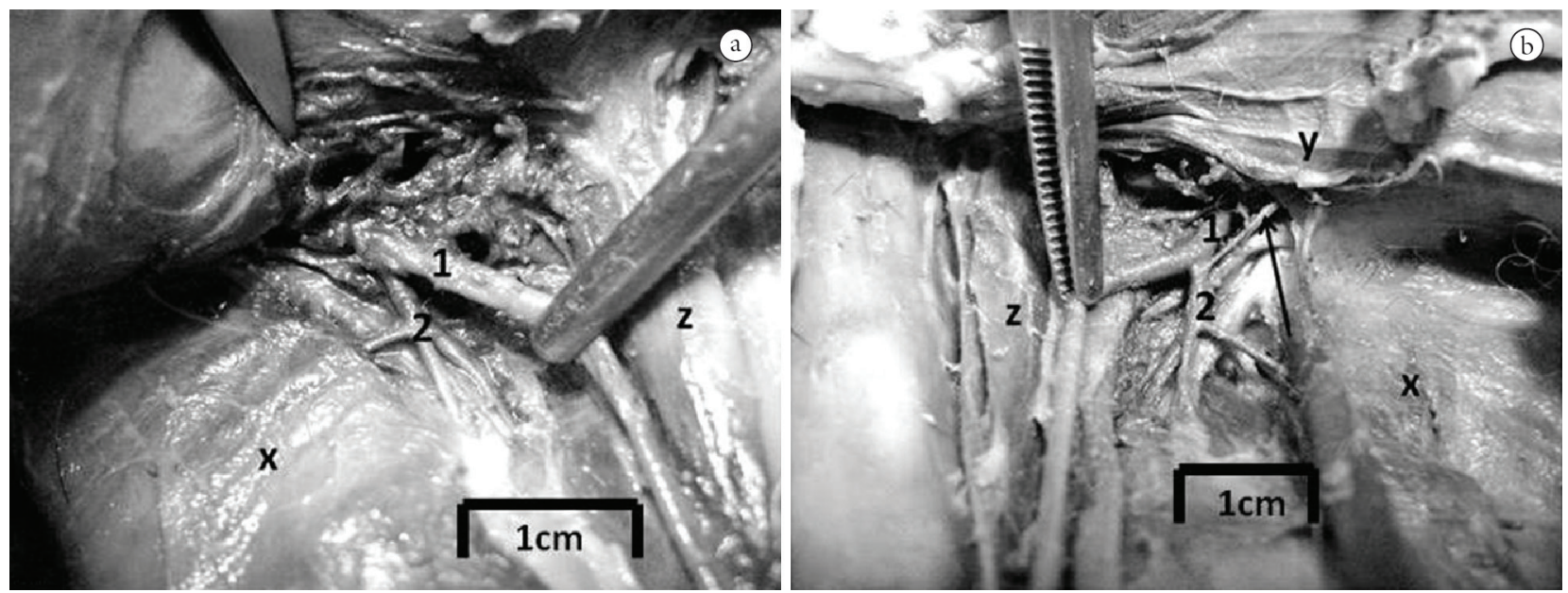

Figure 3. Comparative illustration of the branches of the lateral circumflex femoral artery in A) right thigh and B) left thigh, medial view. X) Adductor muscle; Y) External abdominal oblique muscle; Z) Pectineus muscle; 1) Femoral artery; 2) Lateral circumflex femoral artery. Arrow indicating the branch to the abdominal wall.

CHRISTENSEN, 1979; PIERMATTEI, 1988). Both species have same basic arrangement for the Femoral artery. However, for the Lateral circumflex femoral artery, a significant difference can be noticed. In the domestic dogs the ventral abdominal wall is supplied for the Caudal epigastric artery (KÖNIG and LIEBICH, 2011) against the Lateral circumflex femoral artery in Crab-eating fox. In addition we did not find branches to the Tensor fasciae late, Middle gluteal, Deep gluteal, Iliopsoas muscles and the hip joint capsule in Crab-eating fox as previously described in domestic dogs (EVANS and CHRISTENSEN, 1979; GETTY, 1986).

Accordingly, to the anatomical variation between the left and right limb in our findings, we believe that more samples could explain it. It is not possible to determine a precise specific standard in just one case.

Regarding to epidemiological data, the femoral artery can be easily used to arterial blood sampling (BEAL and HUGHES, 2000) to check the presence of the Leishmania, once the Crab-eating fox is natural reserve of this protozoan (CURI, MIRANDA and TALAMONI, 2006).

Finally, the description of the Femoral artery brought information not only for clinical and surgical procedures in view that the domestic dog can serve as model, but also to comparative morphological studies and biodiversity of the South American fauna.

\section{References}

BARISSON, JD., LOURO, CH., DIAS, SJT., JOJIMA, FS., FERREIRA, MS. and OLIVEIRA, FS. Anatomo-radiographic description of the axial skeleton of the crab-eating fox (Cerdocyon thous). Pesquisa Veterinária Brasileira, 2012, vol. 32, suplemento 1, p. 1-3.

BEAL, MW. and HUGHES, D. Vascular access: Theory and techniques in the small animal emergency patient. Clinical Techniques in Small Animal Practice, 2000, vol. 15, n. 2, p. 101-109. PMid:10998823. http://dx.doi.org/10.1053/svms.2000.6802
CATENACCI, LS., GRISE, J., DA SILVA, RC. and LANGONI, $\mathrm{H}$. Toxoplasma gondii and Leishmania spp. Infection in captive crab-eating foxes, Cerdocyon thous (Carnivora, Canidae) from Brazil. Veterinary Parasitology, 2010, vol. 169, n. 1-2, p. 190-192. PMid:20060648. http://dx.doi.org/10.1016/j. vetpar.2009.12.019

CURI, NH., MIRANDA, I. and TALAMONI, SA. Serologic evidence of Leishmania infection in free-ranging wild and domestic canids around a Brazilian National Park. Memórias do Instituto Oswaldo Cruz, 2006, vol. 101, n. 1, p. 99-101. http://dx.doi. org/10.1590/S0074-02762006000100019

EVANS, HE. and CHRISTENSEN, GC. Miller's Anatomy of the Dog. 2nd ed. Philadelphia: W.B. Saunders Company, 1979. p. $729-40$.

GETTY, R. Sisson/Grossman Anatomia dos Animais Domésticos. 5. ed. Rio de Janeiro: Editora Guanabara Koogan S.A, 1986. 2000 p.

KÖNIG, HE. and LIEBICH, HG. Anatomia dos Animais Domésticos. 4. ed. Porto Alegre: Artmed, 2011. p. 461-494.

LUX HOPPE, EG., ARAÚJO DE LIMA, RC., TEBALDI, JH. and NASCIMENTO, AA. Pterygodermatites (Multipectines) pluripectinata n. sp. (Spirurida: Rictulariidae), a nematode parasite of the crab-eating Fox Cerdocyon thous (Linneaus, 1766) from Caatinga shrubland. Brazilian Journal of Helmintology, 2010, vol. 84, n. 3, p. 312-316.

NAVA, S., VENZAL, JM., LABRUNA, MB., MASTROPAOLO, M., GONZÁLEZ, EM., MANGOLD, AJ. and GUGLIELMONE, AA. Hosts, distribution and genetic divergence (165S rDNA) of Amblioma dubitatum (Acari: Ixodidae). Experimental Applied Acarology, 2010, vol. 51, n. 4, p. 335-351. PMid:20084537. http://dx.doi.org/10.1007/s10493-009-9331-6

NOWAK, RM. Walker's Mammals of the World. 5th Edition. Baltimore and London: John Hopkins University Press, 1991. p. 1045-1062.

PIERMATTEI, DL. and GREELEY, RG. Atlas de abordagens cirúrgicas aos ossos do cães e gato. 2. ed. São Paulo: Editora Manole LTDA, 1988. 203 p. 
ROCHA, VJ., REIS, NR. and SEKIAMA, ML. Dieta e dispersão de sementes por Cerodcyon thous (Linnaeus) (Carnivorae, Canidae), em um fragmento florestal no Paraná, Brasil. Revista Brasileira de Zoologia, 2004, vol. 21, n. 4, p. 871-876. http://dx.doi. org/10.1590/S0101-81752004000400022

SOUZA, NP., ALMEIDA ADO, B., FREITAS, TP., PAZ, RC., DUTRA, V., NAKAZATO, L. and SOUSA, VR. Leishmania (Leishmania) infantum chagasi in wild canids kept in captivity in the State of Mato Grosso. Revista da Sociedade Brasileira de Medicina Tropical, 2010, vol. 43, n. 3, p. 333-335. PMid:20563507.
TCHAICKA, L., EIZIRIK, E., DE OLIVEIRA, TG., CÂNDIDO JÚNIOR, JF. and FREITAS, TRO. Phylogeography and population history of the crab-eating fox (Cerdocyon thous). Molecular Ecology, 2007, vol. 16, n. 4, p. 819-38. PMid:17284214. http:// dx.doi.org/10.1111/j.1365-294X.2006.03185.x

World Association of Veterinary Anatomists. Nomina Anatomica. 5th ed. Hannover, Columbia, Gent, Sapporo: World Association of Veterinary Anatomists, 2005. 166 p.

Received May 16, 2013 Accepted March 15, 2014 